Supplement of Clim. Past, 14, 1565-1581, 2018

https://doi.org/10.5194/cp-14-1565-2018-supplement

(c) Author(s) 2018. This work is distributed under

the Creative Commons Attribution 4.0 License.

(c) (i)

Supplement of

\title{
Effect of high dust amount on surface temperature during the Last Glacial Maximum: a modelling study using MIROC-ESM
}

Rumi Ohgaito et al.

Correspondence to: Rumi Ohgaito (ohgaito@jamstec.go.jp)

The copyright of individual parts of the supplement might differ from the CC BY 4.0 License. 


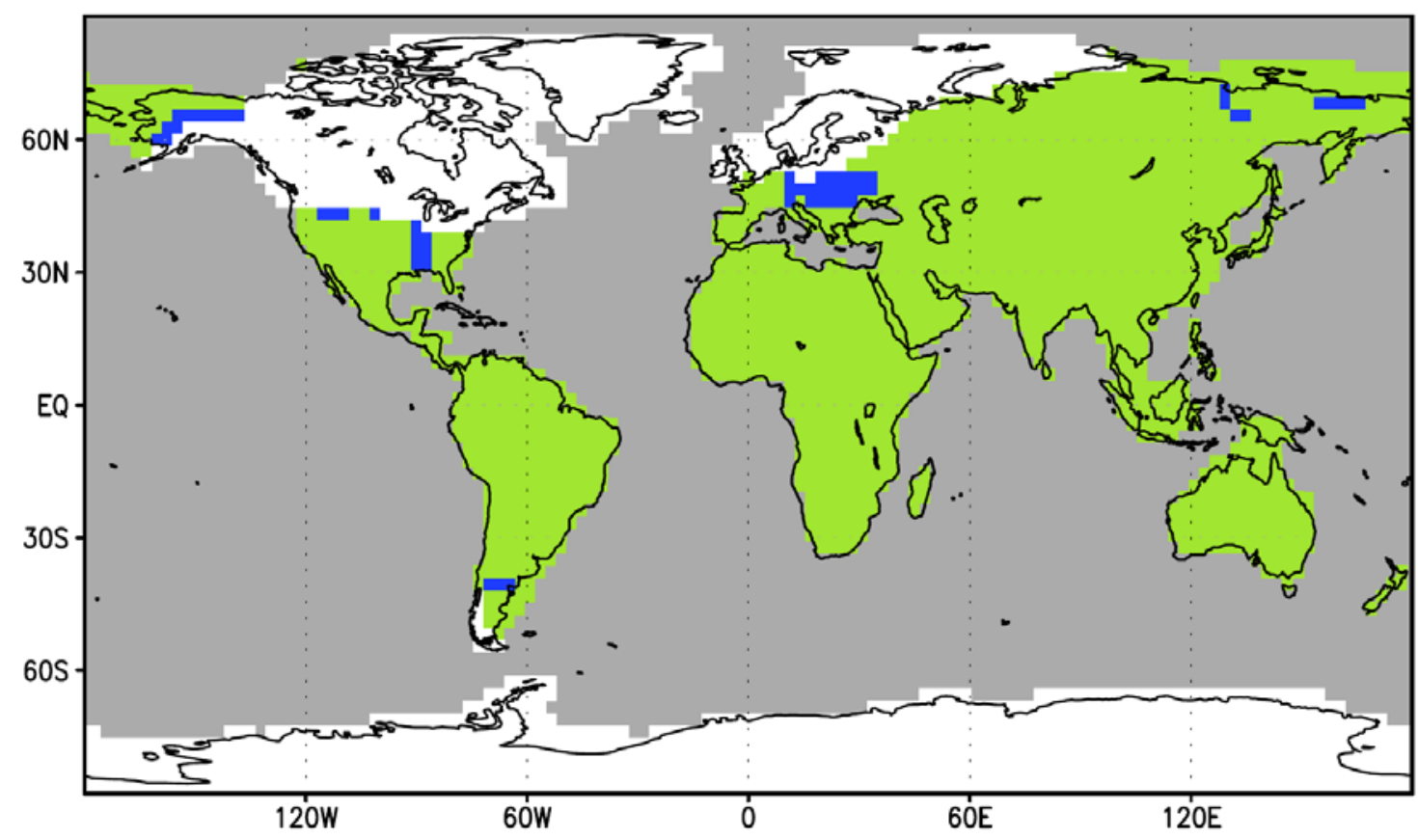

Figure S1: The LGM geographic distribution. Non-gray colors denote land area. blue: glaciogenic dust source area, white: ice sheets area, and green: the other land area. gray: ocean.

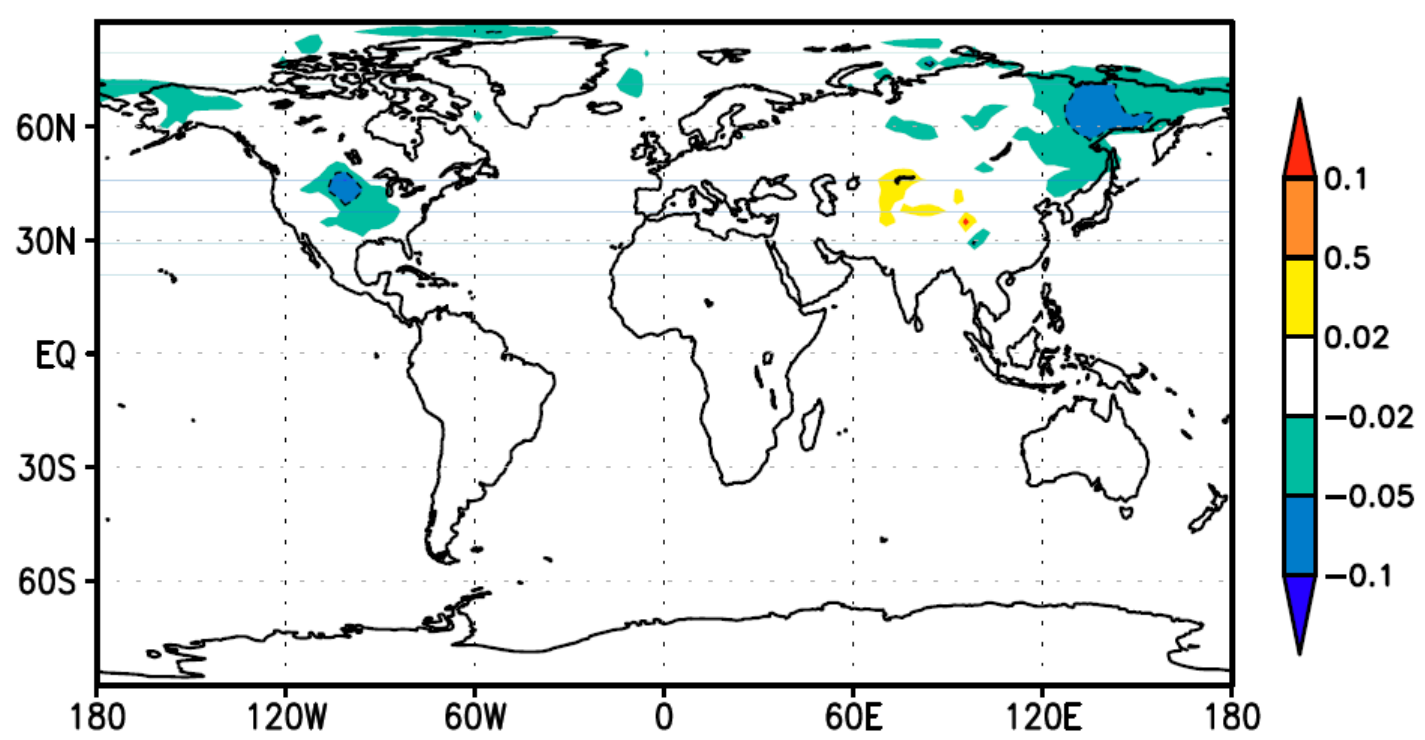

Figure S2: Anomaly of albedo for LGMglac.a-LGM.a. 


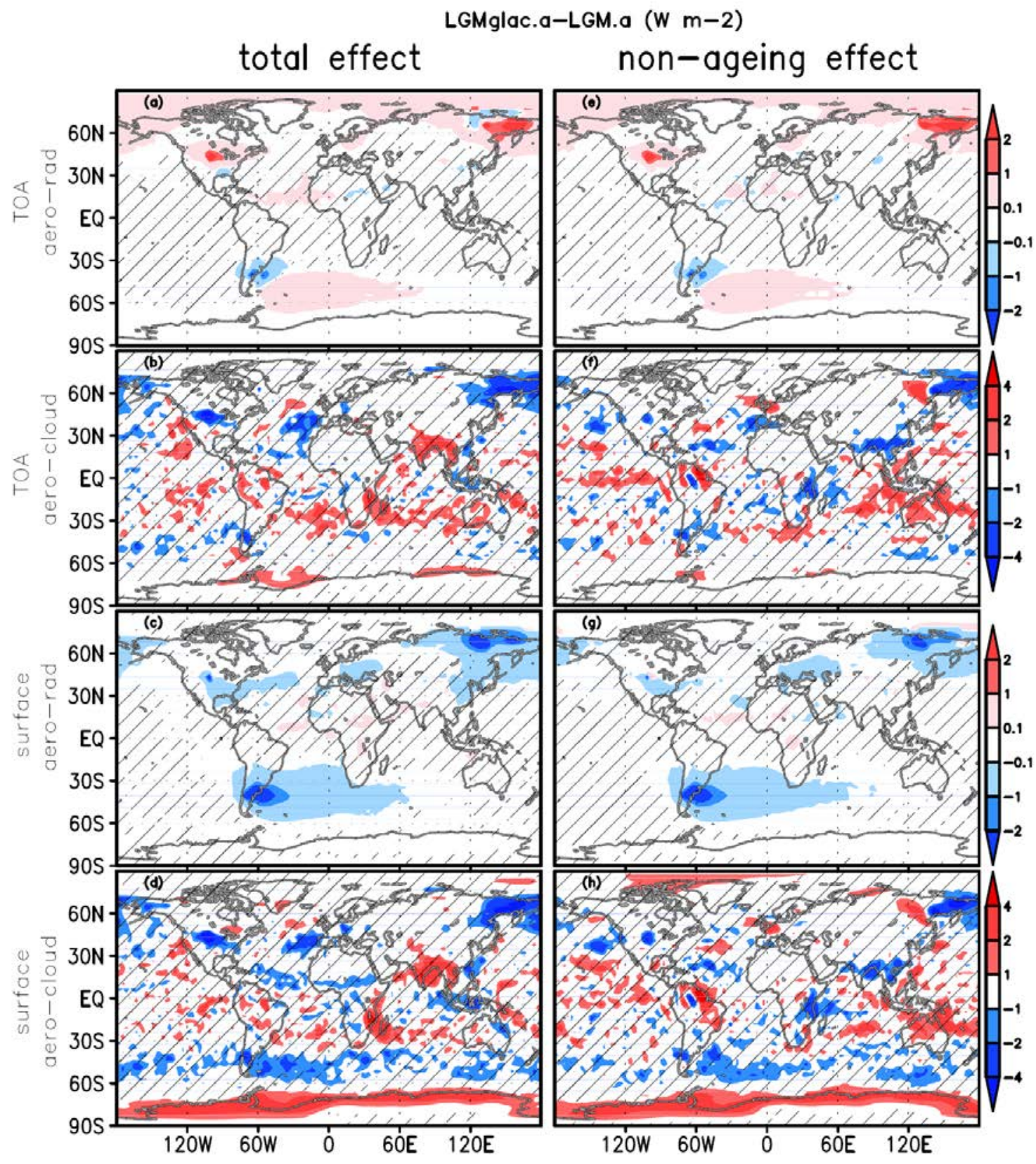

Figure S3: decomposition of the anomaly of radiative perturbation for

LGMglac.a-LGM.a (W m-2) for (a) aerosol-radiation and (b) aerosol-cloud interactions at TOA and for the surface (c), (d) respectively. (e) to (h): the same with (a) to (d) but without ageing effect of snow by dust. Hatched area represent the anomaly is not significant in $95 \%$ confidence by t-test. 


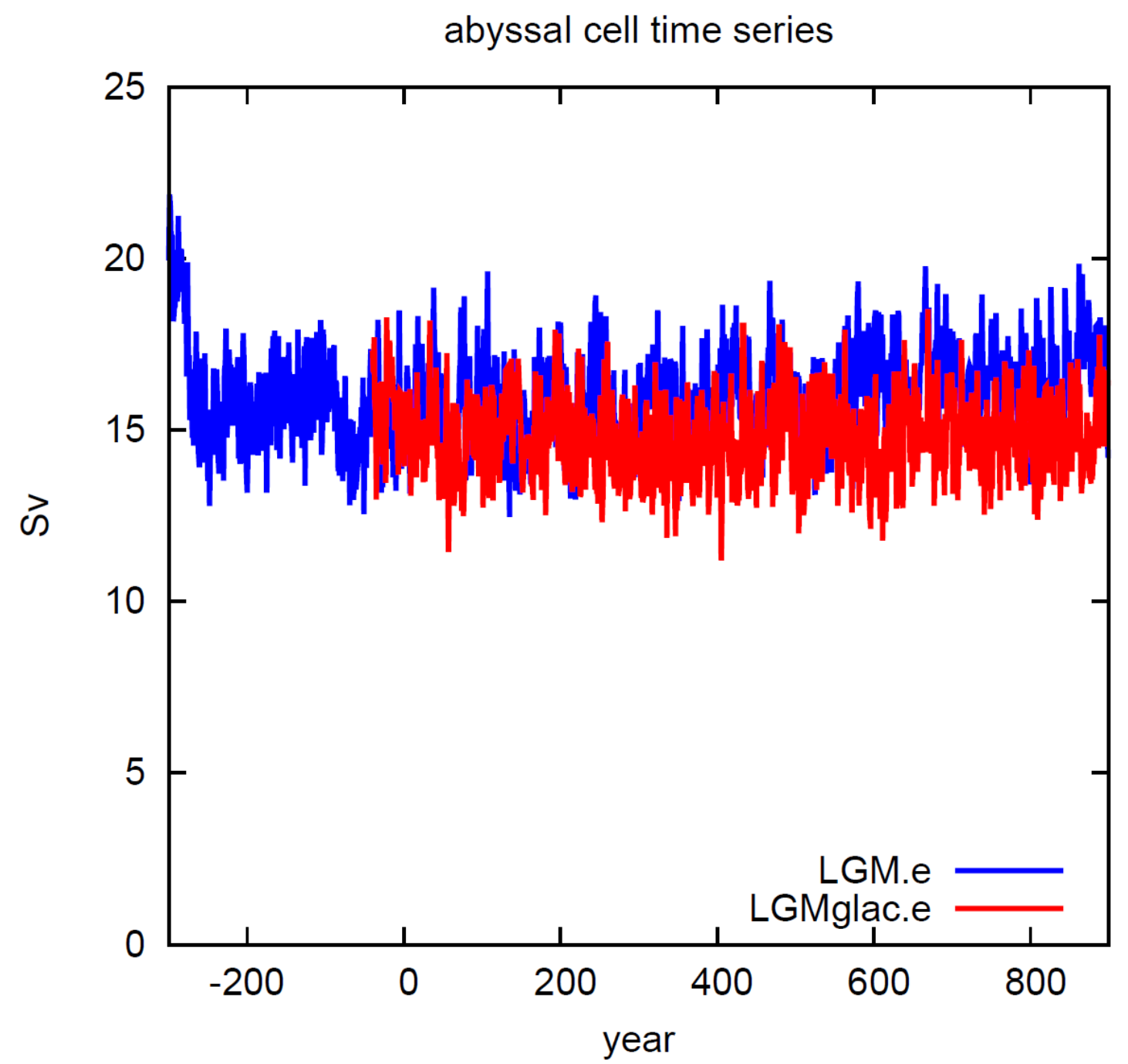

Figure S4: Time series of the index of abyssal cell (Sv) for LGM.e and LGMglac.e in the same format with Figure 1. 


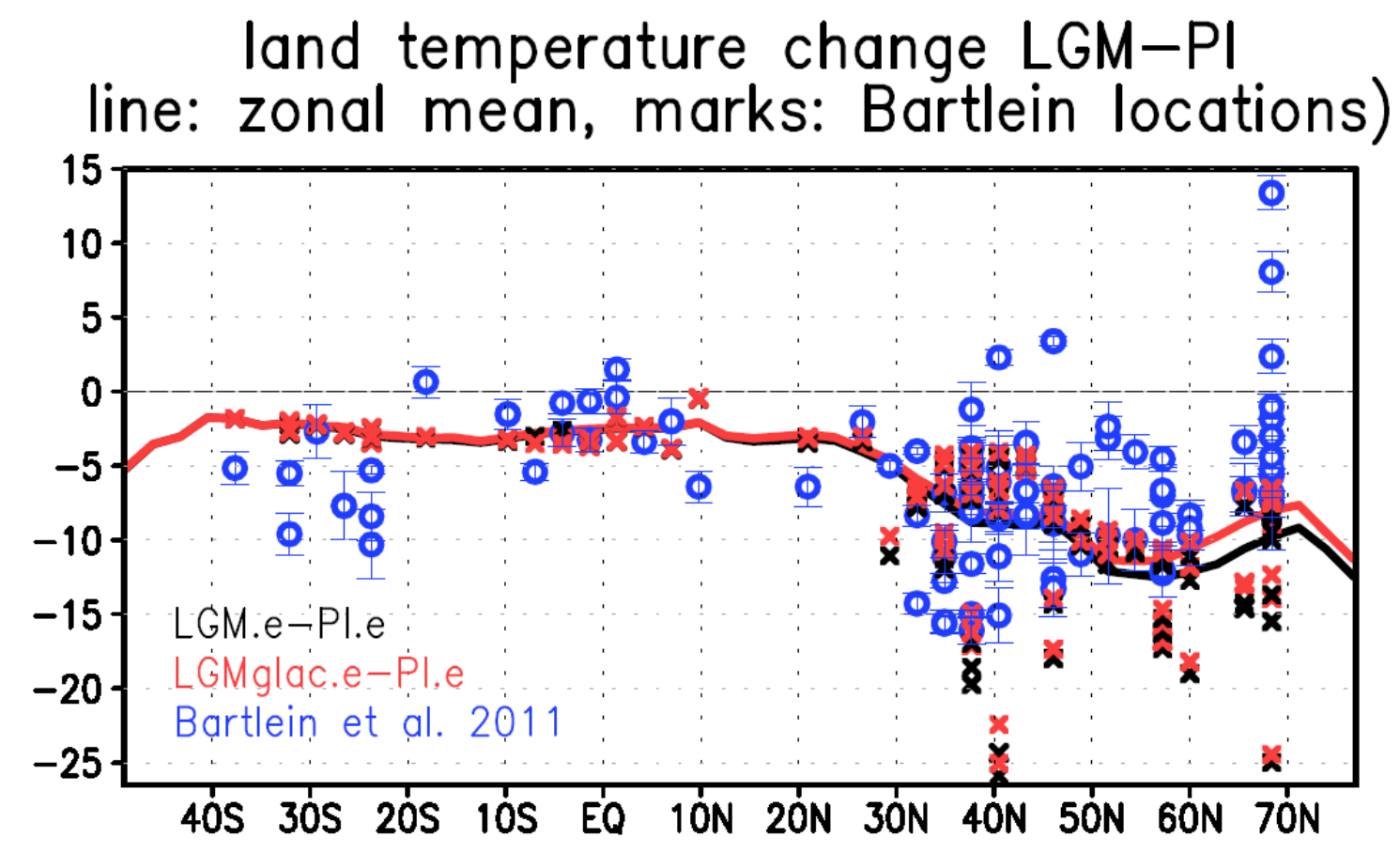

Figure S5: Zonal mean LGM-PI anomaly of the air temperature over land except ice sheets at $2 \mathrm{~m}$ height for LGM.e-PI.e (black line), and LGMglac.e-PI.e (red line). Blue circles denote pollen proxy archive (Bartlein et al. 2011). Black and red crosses represent the values of the corresponding model grids with the proxy data locations. 


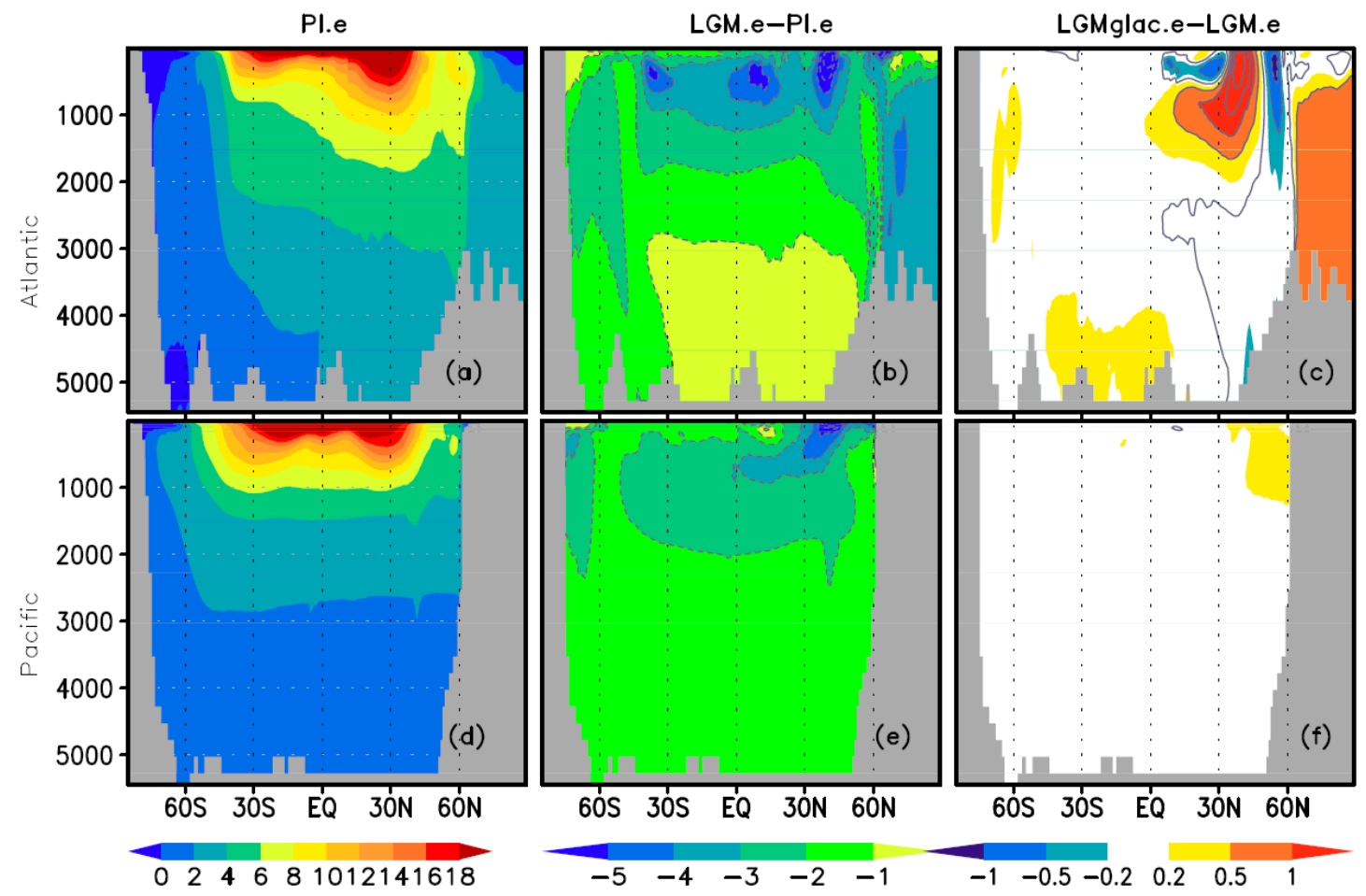

Figure S6: zonal mean oceanic potential temperature for the Atlantic (a, b, c) and Pacific (d, e, f) basins for (a, d) PI.e, anomalies for (b, e) LGM.e-PI.e and for (c, f) LGMglac.e-LGM.e, respectively. 

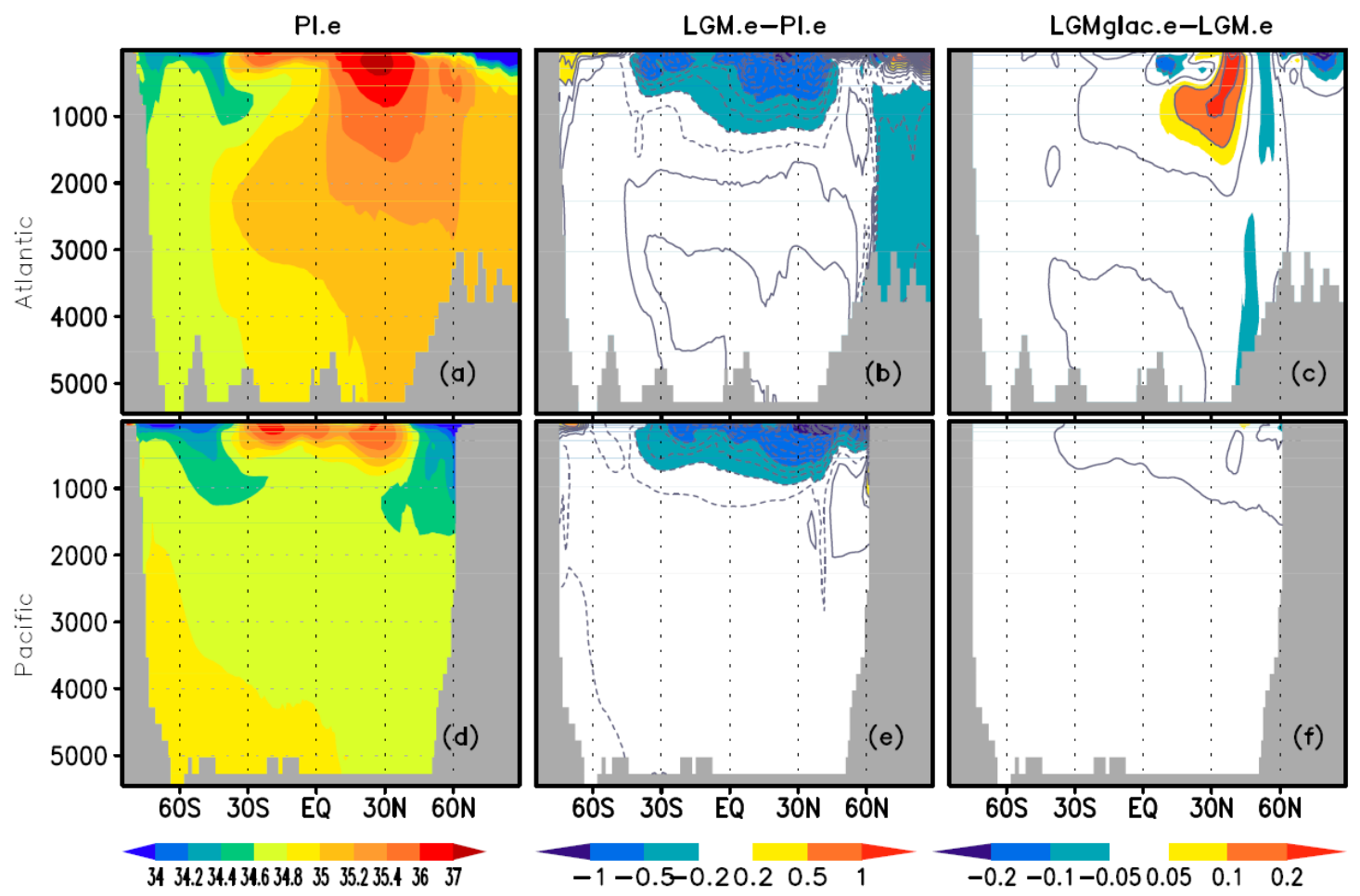

Figure S7: zonal mean oceanic salinity for the Atlantic (a, b, c) and Pacific (d, e, f) basins for (a, d) PI.e, anomalies for (b, e) LGM.e-PI.e and for (c, f) LGMglac.e-LGM.e, respectively in PSU.

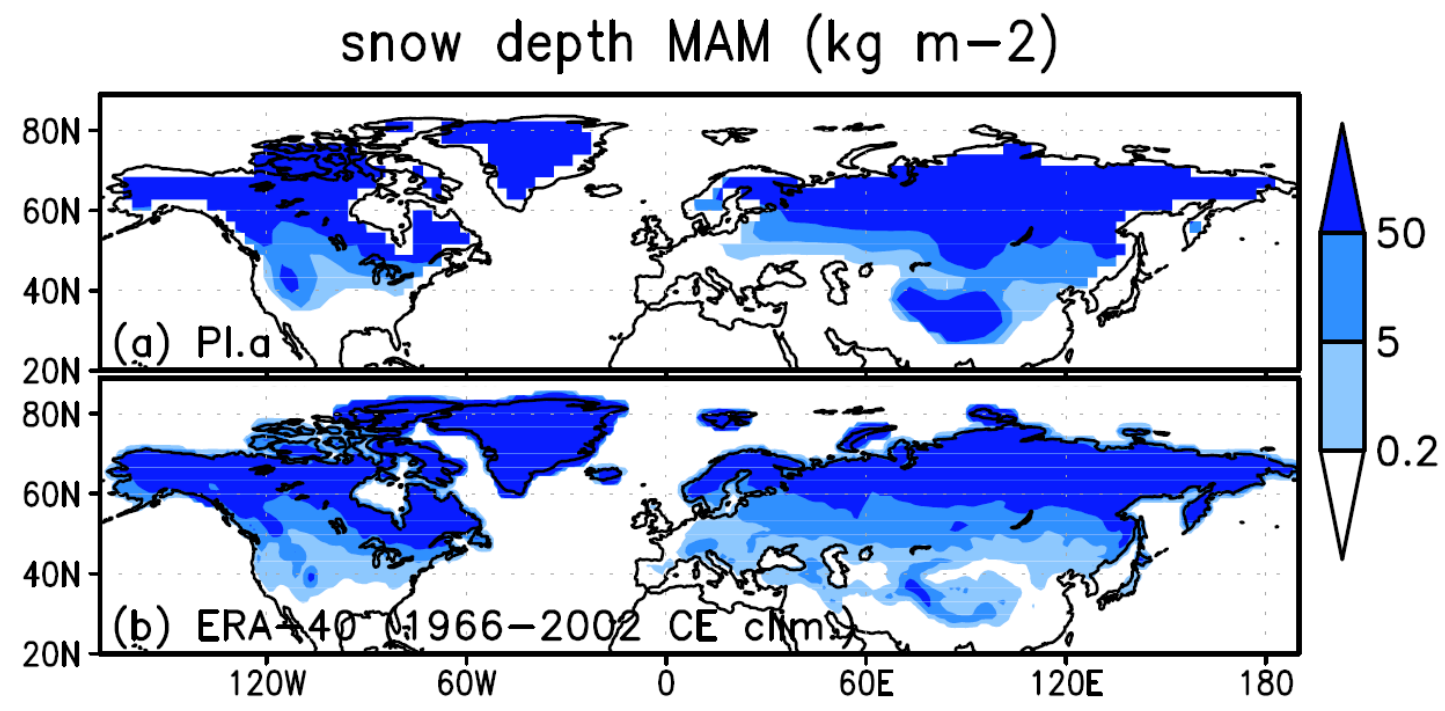

Figure S8: March to May averaged snow amount ( $\mathrm{kg} \mathrm{m}-2)$ for (a) PI.a and (b) ERA40 (1966 CE to 2002 CE climatology). 


\section{References}

Bartlein P. J., Harrison S. P., Brewer S., Connor S., Davis B. A. S., Gajewski K., Guiot J., Harrison-Prentice T. I., Henderson A., Peyron O., Prentice I. C., Scholze M., Seppa H., Shuman B., Sugita S., Thompson R. S., Viau A. E., Williams J. and Wu H. : Pollen-based continental climate reconstructions at 6 and $21 \mathrm{ka}$ : a global synthesis., Climate Dynamics, 37, 775-802, https://doi.org/10.1007/s00382-010-0904-1, 2011.

"The Climate Data Guide: ERA40." Retrieved from https://climatedataguide.ucar.edu/climate-data/era40 